\title{
SIMULASI SISTEM KONTROL KONTROL TEKANAN KOMPRESOR PADA ELECTRICALLY ASSISTED TURBOCHARGER DENGAN METODE CASCADE FUZZY-PI
}

\author{
Satria Indra Nugraha*), Budi Setiyono dan Yuli Christyono \\ Departemen Teknik Elektro, Universitas Diponegoro \\ Jl. Prof. Sudharto, SH, Kampus UNDIP Tembalang, Semarang 50275, Indonesia \\ ${ }^{*}$ E-mail: yohsatria@gmail.com
}

\begin{abstract}
Abstrak
Turbocharger adalah teknologi yang mulai banyak digunakan pada mobil penumpang. Namun turbocharger yang dipasangkan pada spark ignition engine (SI engine) mengalami turbolag dikarenakan perubahan sudut bukaan throttle yang sering terjadi. Hal ini menyebabkan respon sistem menjadi lambat. Beberapa metode yang dilakukan untuk mengurangi turbolag yaitu : penggunaan mesin dengan rasio kompresi tinggi, penempatan katup throttle sebelum kompresor, variable geometry turbocharger, dan pemendekan pipa inlet dan exhaust. Akan tetapi, metode tersebut tidak dapat mengeliminasi turbolag seluruhnya. Salah satu metode untuk mengeliminasi turbolag adalah dengan aktuator tambahan seperti motor DC sebagai electric assist. Motor DC sebagai electric assist dapat memberikan torsi bantu pada turbocharger untuk menghasilkan respon sistem untuk mencapai tekanan kompresor ideal dengan cepat dan stabil pada keadaan tunaknya. Pada penelitian ini dirancang dua struktur sistem kontrol tekanan kompresor pada electrically assisted turbocharger dengan metode cascade fuzzy-PI sehingga motor DC sebagai aktuator tambahan dapat menghasilkan torsi bantu yang sesuai. Hasil pengujian menunjukkan settling time masing-masing struktur 95,99\% dan 95,17\% lebih singkat dibanding sistem turbocharger konvensional.
\end{abstract}

Kata kunci: spark ignition engine, turbocharger, electric assist

\begin{abstract}
Turbocharger is a technology currently popular to be implemented in passenger car. Unfortunately, turbocharger which installed on spark ignition engine suffers turbolag due to the rapid change of throttle valve opening angle. Thus, the systems response is slowed down. Some methods are introduced in order to overcome turbolag such as : using high engine compression ratio, throttle valve before compressor, variable geometry turbocharger, and having short pipe lengths of inlet and exhaust. However, those methods only reduce without eliminate turbolag. One of the turbolag elimination methods is using additional actuator such as DC motor as an electric assist. DC motor as electric assist provides torque assist for turbocharger, thus the system response can quickly reach the ideal compressor pressure and stable at its keadaan tunak. In this paper, two structures of compressor pressure control for electrically assisted turbocharger using cascade fuzzy-PI methods is introduced so that the DC motor as additional actuator can provides suitable torque assist. The research result shows that the settling time of the structures are 95,99\% and 95,17\% respectively faster than the conventional turbocharger.
\end{abstract}

Keywords: spark ignition engine, turbocharger, electric assist

\section{Pendahuluan}

Industri otomotif adalah salah satu industri terbesar di dunia dengan peningkatan jumlah pengguna mobil di Indonesia yang terus bertambah banyak setiap tahunnya. Gabungan Industri Kendaraan Bermotor Indonesia (GAIKINDO) mencatat penjualan mobil pada tahun 2016 mencapai angka 1.060.000 unit, 4,5 \% lebih tinggi dibanding penjualan pada tahun 2015. Mobil-mobil baru didesain sedemikian rupa sehingga spark ignition engine
(SI engine) yang ada pada kendaraan memiliki tiga elemen penting, yaitu : performa yang andal, rendah emisi, dan hemat bahan bakar. Dari ketiga hal tersebut, performa yang andal dari mesin adalah salah satu elemen yang dapat memastikan kendaraan mampu mengatasi berbagai medan dan memberikan pengalaman berkendara yang memuaskan, oleh karena itu dilakukan berbagai penelitian untuk meningkatkan performa mesin. Peningkatan performa mesin telah dilakukan melalui beberapa penelitian, antara lain : penggantian jenis bahan bakar, 
pengubahan rasio kompresi, pengontrolan air-to-fuel ratio (AFR), dan pengubahan struktur naturally aspirated SI engine menjadi forced induction SI engine dengan penambahan turbocharger [1]-[4].

Turbocharger pada SI engine memiliki kelemahan yaitu lag dari turbocharger yang disebut turbolag. SI engine adalah mesin yang lebih responsif dibanding mesin diesel, sehingga waktu tunda dari turbocharger dalam meningkatkan suplai udara ke dalam mesin menjadi gangguan yang berpengaruh lebih signifikan pada SI engine dibanding pada mesin diesel [4]. SI engine bekerja pada rentang laju aliran massa yang jauh lebih luas dari mesin diesel sehingga kebutuhan aliran udara dapat berubah-ubah dengan cepat dan turbolag akan sangat terasa oleh pengemudi, oleh karena itu turbolag harus dapat diatasi.

Desain turbocharger yang diproduksi selalu diperbaiki. Beberapa cara yang dapat dilakukan untuk mengatasi turbolag, yaitu : penggunaan mesin dengan rasio kompresi yang tinggi, peletakkan throttle sebelum kompresor, penggunaan waste gate controller, penggunaan variable geometry turbocharger (VGT), penggunaan low-inertia pulse turbocharger system, dan pemendekan pipa inlet dan exhaust, namun cara-cara tersebut hanya mengurangi dan tidak mengeliminasi turbolag secara keseluruhan. Salah satu cara untuk mengeliminasi turbolag adalah dengan melakukan injeksi udara langsung pada turbin, namun metode ini memerlukan AFR dalam kondisi rich agar temperatur udara yang masuk ke dalam turbin meningkat sehingga kerja turbin meningkat, namun metode tersebut memberikan beban yang berat pada pipa-pipa exhaust sehingga mengurangi masa pakai dari turbin turbocharger. Metode lain untuk mengatasi turbolag adalah dengan electrically assisted turbocharger (EAT). Beberapa penelitian tentang EAT meliputi pemodelan dan desain sistem kontrol EAT pada hybrid electric vehicle, penggunaan EAT pada kendaraan berat, pendeskripsian masalah teknis pemilihan jenis mesin untuk dipadukan dengan EAT, perbandingan topologi magnet permanen pada performa mesin dengan EAT, dan perpaduan EAT dengan exhaust gas recirculation [5]-[9], namun fokus penelitian EAT secara umum adalah pada desain mekanik sistem, belum merinci pada sistem kontrol yang digunakan dalam pengendalian motor untuk EAT.

Pada Penelitian ini, dirancang sistem kontrol tekanan kompresor pada EAT untuk mengatasi turbolag pada turbocharger. Pada Penelitian ini digunakan sistem kontrol cerdas fuzzy logic controller yang dipadukan dengan sistem kontrol proporsional-integral (PI) untuk mengendalikan motor pada EAT dengan dua struktur cascade yang berbeda. Fuzzy logic controller digunakan untuk mengatur torsi electric assist yang dibutuhkan dan melakukan gain scheduling pada sistem kontrol PI untuk memastikan keluaran sistem yang memuaskan. Evaluasi sistem yang dirancang dilakukan dengan melihat respon transien, respon keadaan tunak, dan integral squared error (ISE). Kedua sistem yang dirancang dibandingkan sistem dengan turbocharger konvensional.

\section{Metode \\ 2.1. Turbocharger}

Turbocharger merupakan perangkat yang digunakan untuk melakukan supercharging [4]. Struktur turbocharger ditunjukkan pada Gambar 1.

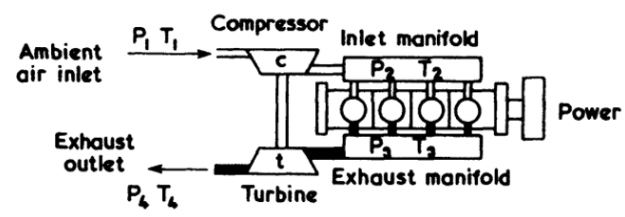

\section{Gambar 1. Struktur turbocharger.}

Turbocharger memanfaatkan gas buang pada bagian exhaust untuk memutar turbin. Turbin yang dihubungkan oleh turboshaft pada kompresor menyebabkan kompresor berputar. Putaran kompresor menyebabkan udara yang masuk ke mesin terkompresi sehingga kerapatan udara meningkat. Dengan meningkatnya kerapatan udara, maka suplai bahan bakar yang diberikan akan meningkat untuk menjaga nilai AFR tetap, hal ini menyebabkan daya mesin meningkat [4]. Secara umum, turbocharger dilengkapi blow off valve untuk mencegah lonjakan tekanan yang terjadi bila sudut bukaan throttle diperkecil dan waste gate untuk mencegah tekanan turbin terlalu besar.

\subsubsection{Model tekanan turbocharger}

Tekanan turbin dan kompresor pada turbocharger dimodelkan berdasarkan persamaan gas ideal [10]. Tekanan dimodelkan berdasarkan perbedaan laju aliran massa yang masuk dan meninggalkan sistem. Model tekanan turbin dan kompresor ditunjukkan pada persamaan (1) dan persamaan (2).

$$
\begin{aligned}
& p_{t}=\frac{R \cdot T_{t}}{V_{t}} \int\left(\dot{m}_{t}-\dot{m}_{e m}\right) d t \\
& p_{c}=\frac{R \cdot T_{c}}{V_{c}} \int\left(\dot{m}_{a f}-\dot{m}_{c}\right) d t
\end{aligned}
$$

\section{Dengan :}

$p_{t} \quad=$ tekanan turbin $(\mathrm{Pa})$

$p_{c} \quad=$ tekanan $\operatorname{kompresor}(\mathrm{Pa})$

$T_{t} \quad=$ temperatur turbin $(\mathrm{K})$

$T_{c} \quad=$ temperatur kompresor $(\mathrm{K})$

$\dot{m}_{t} \quad=$ laju aliran massa pada turbin $(\mathrm{kg} / \mathrm{s})$

$\dot{m}_{c} \quad=$ laju aliran massa pada kompresor $(\mathrm{kg} / \mathrm{s})$

$\dot{m}_{a f} \quad=$ laju aliran massa pada tapis udara $(\mathrm{kg} / \mathrm{s})$

$\dot{m}_{e m} \quad=$ laju aliran massa pada exhaust manifold $(\mathrm{kg} / \mathrm{s})$ 


$$
\begin{array}{ll}
V_{t} & =\text { volume turbin }\left(\mathrm{m}^{3}\right) \\
V_{c} & =\text { volume } \\
\mathrm{R} & =\text { vompresoranta gas spesifik }(\mathrm{J} / \mathrm{kg} . \mathrm{K})
\end{array}
$$

\subsubsection{Model laju aliran massa}

Laju aliran massa turbin dan kompresor dimodelkan seperti pada persamaan (3) [11], [12].

$$
\begin{aligned}
& \dot{m}_{t}=\frac{C_{d} A p_{e m} f_{\Pi t}}{\sqrt{R T_{e m}}} \\
& \dot{m}_{c}=\frac{p_{a f} \pi r_{c}{ }^{3} \omega_{t c}}{R T_{a f}} \Phi_{c}
\end{aligned}
$$

$$
\text { Dengan : }
$$

$A \quad=$ Luas penampang turbin

$C_{d} \quad=$ koefisien discharge

$f_{\Pi t} \quad=$ fungsi rasio tekanan

$T_{\text {em }} \quad=$ Temperatur exhaust manifold $(\mathrm{K})$

$\dot{m}_{t} \quad=$ laju aliran massa pada turbin $(\mathrm{kg} / \mathrm{s})$

$\dot{m}_{c} \quad=$ laju aliran massa pada kompresor $(\mathrm{kg} / \mathrm{s})$

$p_{a f} \quad=$ tekanan tapis udara $(\mathrm{Pa})$

$T_{a f} \quad=$ temperatur tapis udara $(\mathrm{Pa})$

$r_{c} \quad=$ jari-jari $\operatorname{kompresor}(\mathrm{m})$

$\Phi_{c} \quad=$ koefisien aliran volumetrik

Model pada persamaan (3) dan persamaan (4) merupakan model turbocharger dengan variable geometry turbocharger. Pada penelitian ini, variable geometry turbocharger tidak digunakan untuk penyederhanaan model.

\subsection{Electrically Assisted Turbocharger}

Skema plant SI engine dengan EAT ditunjukkan pada Gambar 2 [13].

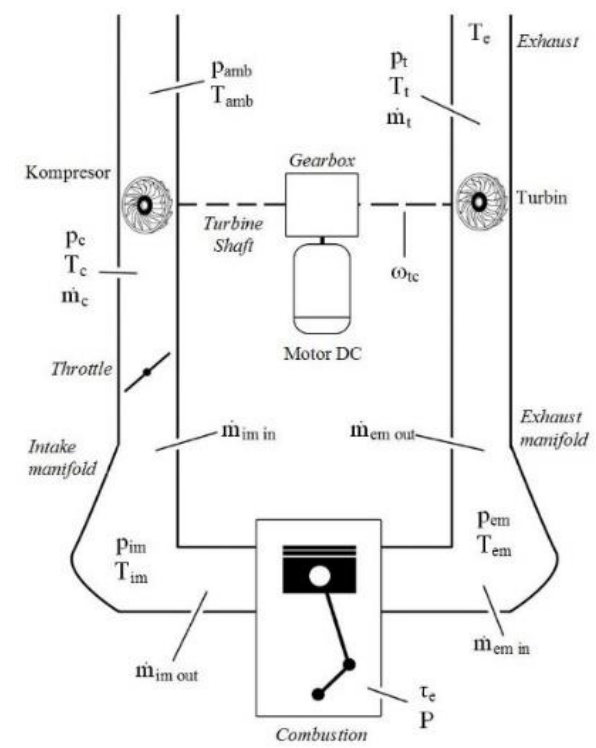

Gambar 2. Skema plant SI engine dengan EAT.

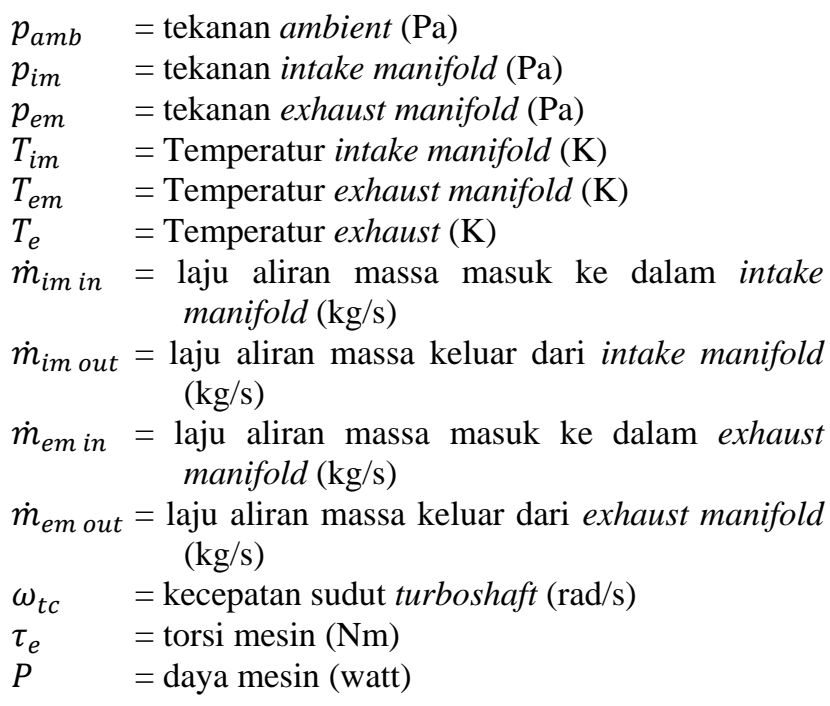

Pada penelitian ini, sistem EAT yang dirancang tidak dilengkapi blow off valve dan waste gate untuk penyederhanaan model. Pada sistem yang dirancang, motor DC berperan sebagai aktuator tambahan dimana torsi motor menjadi torsi bantu untuk memutar turboshaft. Gearbox yang menghubungkan motor DC pada turboshaft dimodelkan sebagai summing point.

\subsection{Sistem Kontrol Cascade}

Dikarenakan pengontrolan tekanan dilakukan secara tidak langsung dimana pengontrolan dilakukan melalui aktuator yaitu motor DC, maka sistem kontrol pada penelitian ini menggunakan struktur cascade yang ditunjukkan pada Gambar 3.

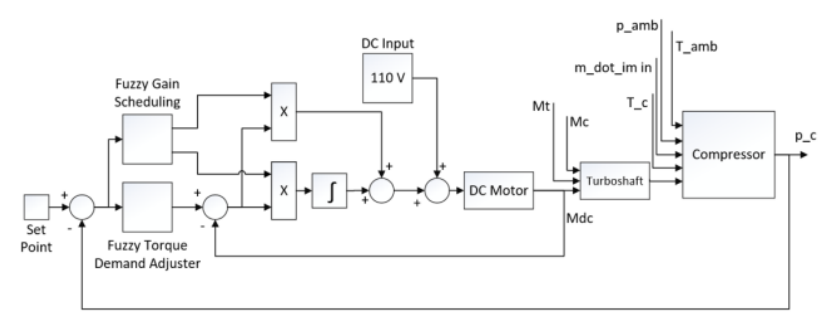

(a) Cascade fuzzy gain scheduling of PI.

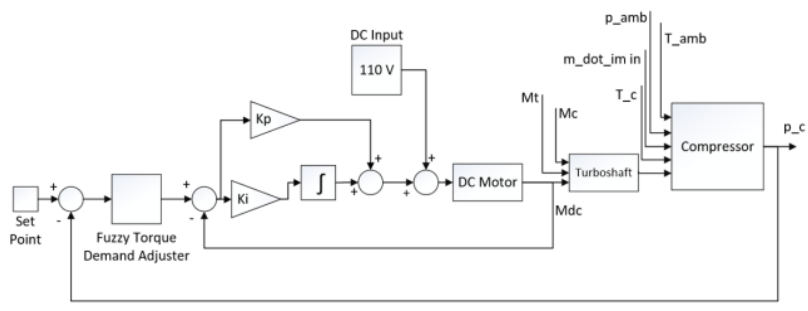

(b) Cascade fuzzy-PI.

Gambar 3. Struktur kontroler cascade.

Kedua struktur memiliki perbedaan dimana struktur pada Gambar 3 (a) menggunakan gain scheduling sedangkan 
struktur pada Gambar 3 (b) menggunakan gain proporsional dan gain integral tetap.

Fuzzy torque demand adjuster digunakan untuk mengatur besar torsi motor yang diperlukan untuk menjadi torsi bantu. Fuzzy torque demand adjuster didesain berdasarkan pengujian yang dilakukan dimana torsi bantu yang dibutuhkan berada dalam rentang $-1,5 \mathrm{Nm}$ hingga $+1,5$ Nm. Fuzzy torque demand adjuster merupakan fuzzy logic controller dua masukan satu keluaran dimana masukannya adalah galat dan perubahan galat, sedangkan keluarannya berupa besar torsi yang dibutuhkan. Variabel masukan fuzzy torque demand adjuster ditunjukkan pada Gambar 4 dan fungsi keluaran fuzzy torque demand adjuster ditunjukkan pada Tabel 1.

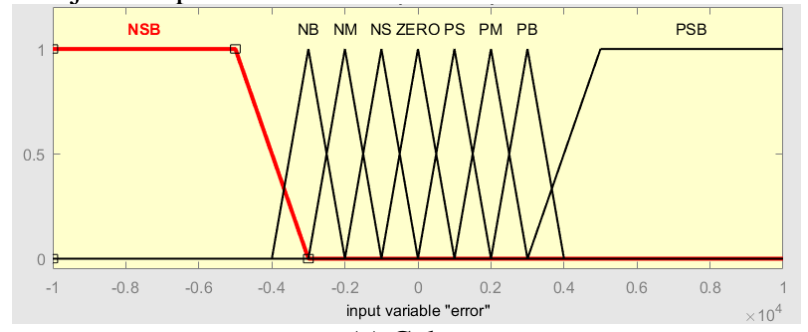

(a) Galat.

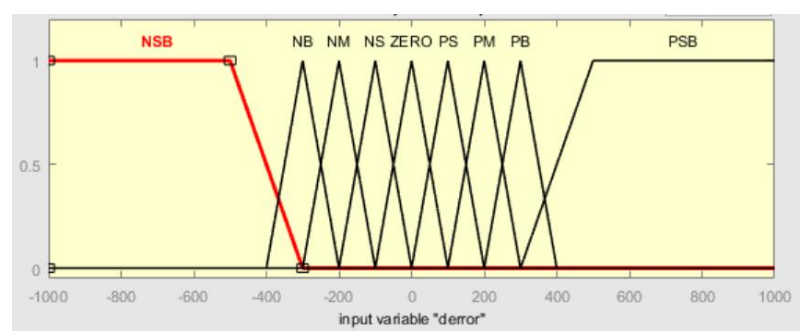

(b) Perubahan galat.
Gambar 4. Fungsi keanggotaan masukan fuzzy torque demand adjuster.

Tabel 1. Fungsi keanggotaan keluaran fuzzy torque demand adjuster.

\begin{tabular}{ccc}
\hline Fungsi Keanggotaan & Simbol & Nilai \\
\hline MegaBig & MB & 1,5 \\
VeryBig & VB & 1,2 \\
Big & B & 0,9 \\
Moderate & M & 0,6 \\
Small & S & 0,3 \\
Zero & Z & 0 \\
nSmall & NS & $-0,3$ \\
nModerate & NM & $-0,6$ \\
nBig & NB & $-0,9$ \\
nVeryBig & NVB & $-1,2$ \\
nMegaBig & NMB & $-1,5$ \\
\hline
\end{tabular}

Fungsi keanggotaan yang telah ditentukan digunakan dalam struktu fuzzy Sugeno dengan aturan yang ditentukan berdasarkan pengujian. Aturan fuzzy untuk fuzzy torque adjuster ditunjukkan pada Tabel 2. Aturan disesuaikan dengan dinamika mesin dan menjadi set point untuk sistem kontrol PI.

Pada struktur cascade fuzzy-PI, gain proporsional dan gain intergral ditentukan berdasarkan cepat lambatnya respon sistem dan sifat robust sistem. Berdasarkan pengujian, diperoleh nilai gain proporsional, $K_{p}=91$, dan gain integral, $K_{i}=1.825$.

Tabel 2. Aturan fuzzy untuk fuzzy torque demand adjuster.

\begin{tabular}{|c|c|c|c|c|c|c|c|c|c|c|}
\hline & & \multicolumn{9}{|c|}{ Variabel masukan perubahan galat } \\
\hline & & NSB & NB & NM & NS & Zero & PS & PM & PB & PSB \\
\hline \multirow{9}{*}{ 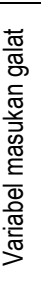 } & NSB & NMB & NMB & NMB & NMB & NMB & NMB & NMB & NMB & NMB \\
\hline & NB & NVB & NVB & NMB & NMB & NMB & NMB & NMB & NMB & NMB \\
\hline & NM & NM & NM & NB & NB & NVB & NVB & NVB & NVB & NVB \\
\hline & NS & NS & NS & NS & NS & NM & NB & NB & NB & NB \\
\hline & Zero & Z & Z & Z & Z & Z & Z & Z & Z & Z \\
\hline & PS & Z & Z & Z & Z & B & B & B & B & B \\
\hline & PM & $M$ & $M$ & $B$ & B & VB & VB & VB & VB & VB \\
\hline & PB & VB & VB & MB & $\mathrm{MB}$ & $\mathrm{MB}$ & $\mathrm{MB}$ & $\mathrm{MB}$ & $\mathrm{MB}$ & VB \\
\hline & PSB & $\mathrm{MB}$ & $\mathrm{MB}$ & MB & $\mathrm{MB}$ & $\mathrm{MB}$ & $\mathrm{MB}$ & $\mathrm{MB}$ & $\mathrm{MB}$ & $\mathrm{MB}$ \\
\hline
\end{tabular}


Pada struktur cascade fuzzy gain scheduling of PI,,dilakukan scheduling pada gain proporsional dan gain integral agar gain proporsional dan gain integral sistem selalu optimal pada setiap bagian respon sistem. Gain scheduling dirancang menggunakan fuzzy logic controller dengan struktur Sugeno dengan masukan galat tekanan. Keluaran dari fuzzy logic controller untuk gain scheduling merupakan gain proporsional dan gain integral. Fungsi keanggotaan galat dari fuzzy logic controller untuk gain scheduling ditunjukkan pada Gambar 5.

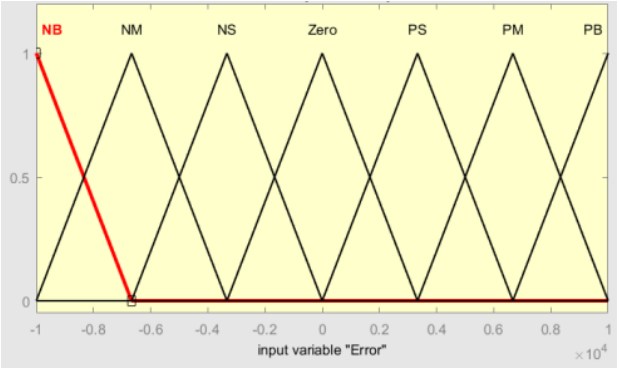

Gambar 5. Fungsi keanggotaan masukan fuzzy gain scheduling.

Variabel keluaran fuzzy gain scheduling ditunjukkan pada Tabel 3.

Tabel 3. Variabel keluaran fuzzy gain scheduling.

\begin{tabular}{cccc}
\hline Variabel Keluaran & Fungsi Keanggotaan & Simbol & Nilai \\
\hline $\mathrm{K}_{\mathrm{p}}$ & Big & $\mathrm{B}$ & 95 \\
& Moderate & $\mathrm{M}$ & 55 \\
& Small & $\mathrm{S}$ & 10 \\
$\mathrm{~K}_{\mathrm{i}}$ & Big & $\mathrm{B}$ & 1825 \\
& Moderate & $\mathrm{M}$ & 1000 \\
& Small & $\mathrm{S}$ & 500 \\
\hline
\end{tabular}

Aturan fuzzy gain scheduling diatur berdasarkan nilai optimal gain proporsional dan gain integral tiap bagian respon sistem. Aturan fuzzy gain scheduling ditunjukkan pada Tabel 4.

Tabel 4. Aturan fuzzy gain scheduling.

\begin{tabular}{ccc}
\hline Galat & $\mathbf{K}_{\mathbf{p}}$ & $\mathbf{K}_{\mathbf{i}}$ \\
\hline NB & B & B \\
NM & B & B \\
NS & B & B \\
Zero & B & B \\
PS & M & M \\
PM & M & M \\
PB & S & S \\
\hline
\end{tabular}

\section{Hasil dan Analisa}

Pada penelitian ini dilakukan pengujian tanpa gangguan, pengujian akselerasi, dan pengujian perpindahan transmisi. Setiap pengujian dilakukan dengan empat variasi transmisi. Pengujian gangguan negatif digunakan untuk menguji kemampuan sistem menggantikan blow off valve mencegah lonjakan tekanan saat sudut bukaan throttle diperkecil.

Pengujian tanpa gangguan dilakukan dengan lima variasi sudut bukaan throttle, yaitu : $20^{\circ}, 30^{\circ}, 45^{\circ}, 60^{\circ}$, dan $90^{\circ}$. Hasil pengujian pada transmisi 1 dan sudut bukaan throttle $20^{\circ}$ ditunjukkan pada Gambar 6.

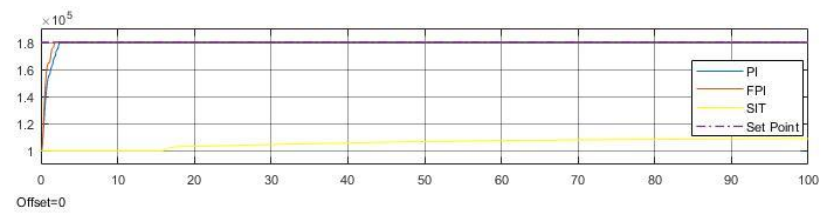

Gambar 6. Respon keluaran sistem pada transmisi 1 dan sudut bukaan throttle $20^{\circ}$.

Dengan :

$P I \quad=$ sistem dengan struktur cascade fuzzy-PI.

FPI = sistem dengan struktur cascade fuzzy gain scheduling of PI.

SIT = sistem turbocharger konvensional

Dari Gambar 6 terlihat bahwa sistem dengan struktur cascade fuzzy gain scheduling of PI memiliki respon sistem yang lebih cepat dibandingkan sistem dengan struktur cascade fuzzy-PI. Kedua struktur mampu menunjukkan respon sistem yang jauh mengungguli sistem turbocharger konvensional. Pengujian variasi lain menunjukkan trend respon yang sama dengan respon pada Gambar 6. Nilai rata-rata hasil pengujian tanpa gangguan ditunjukkan pada Tabel 5.

Tabel 5. Hasil rata-rata pengujian tanpa gangguan.

\begin{tabular}{clcccc}
\hline Transmisi & $\begin{array}{c}\text { Sistem } \\
\text { Kontrol }\end{array}$ & $\begin{array}{c}\text { Settling } \\
\text { Time } \mathbf{( s )}\end{array}$ & $\begin{array}{c}\text { Galat } \\
\text { Keadaan } \\
\text { Tunak (Pa) }\end{array}$ & ISE & $\begin{array}{c}\text { Torsi } \\
\text { (Nm) }\end{array}$ \\
\hline 1 & EAT PI & 2,54 & 356 & $3,475.10^{9}$ & 315,6 \\
1 & EAT FPI & 1,88 & 441 & $2,690.10^{9}$ & 317,3 \\
1 & SIT & - & 67.728 & $5,220.10^{11}$ & 189,2 \\
2 & EAT PI & 3,02 & 166 & $4,001.10^{9}$ & 296,4 \\
2 & EAT FPI & 2,38 & 154 & $2,978.10^{9}$ & 296,4 \\
2 & SIT & - & 46.459 & $3,802.10^{11}$ & 219,9 \\
3 & EAT PI & 3,9 & 257 & $5,138.10^{9}$ & 281,2 \\
3 & EAT FPI & 3,2 & 259 & $3,756.10^{9}$ & 281,2 \\
3 & SIT & 66 & 43.485 & $2,696.10^{11}$ & 293,7 \\
4 & EAT PI & 5,12 & 468 & $7,632.10^{9}$ & 265,0 \\
4 & EAT FPI & 4,66 & 487 & $5,989.10^{9}$ & 265,0 \\
4 & SIT & 46 & 35.864 & $2,159.10^{11}$ & 277,1 \\
Rata-rata & EAT PI & 3,645 & 312 & $5,064.10^{9}$ & 289,6 \\
Rata-rata & EAT FPI & 3,03 & 335 & $3,853.10^{9}$ & 290,0 \\
Rata-rata & SIT & 75,5 & 48.259 & $3,469.10^{11}$ & 245,1 \\
\hline
\end{tabular}

Berdasarkan Tabel 5, terlihat bahwa sistem cascade fuzzy gain scheduling of PI memiliki settling time 95,99\% lebih singkat dibanding sistem turbocharger konvensional. Sistem cascade fuzzy-PI memiliki settling time 95,17\% lebih singkat dibanding sistem turbocharger konvensional. 
Hal ini menunjukkan kedua struktur mampu mengatasi turbolag. Pada Tabel 5 terlihat bahwa sistem fuzzy gain scheduling of PI memiliki nilai ISE 23,9 \% lebih rendah dibanding sistem cascade fuzzy-PI. Sesuai sifat ISE yang lebih menitikberatkan pada galat yang besar dan galat kecil lebih ditoleransi, ISE yang kecil menunjukkan respon transien sistem cascade fuzzy gain scheduling of PI lebih singkat dibanding cascade fuzzy-PI. Galat keadaan tunak sistem cascade fuzzy gain scheduling of PI lebih tinggi dibanding sistem cascade fuzzy-PI namun keduanya masih dalam rentang toleransi yaitu $170.000 \mathrm{~Pa}$ hingga 190.000 $\mathrm{Pa}$.

Turbolag tidak hanya terjadi pada respon awal sistem namun juga apabila terjadi gangguan positif berupa sudut bukaan throttle diperbesar. Pengujian dengan gangguan positif dilakukan dengan kondisi bukaan throttle awal $20^{\circ}$. pengujian pada transmisi 1 dengan gangguan positif $+30^{\circ}$ pada $t=25$ dan $+20^{\circ}$ pada $t=50$ ditunjukkan pada Gambar 7.

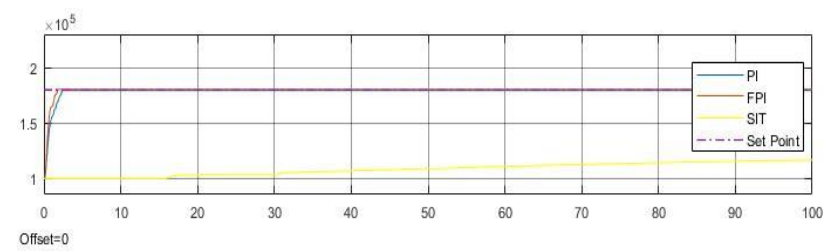

Gambar 7. Respon keluaran sistem pada engine transmisi 1 dengan gangguan positif $+30^{\circ}$ dan $+20^{\circ}$.

Gambar 7 menunjukkan bahwa sistem cascade fuzzy gain scheduling of PI dan sistem cascade fuzzy-PI dapat menjaga respon sistem tetap berada dalam keadaan tunaknya sementara sistem turbocharger konvensional mengalami kenaikan tekanan. Pengujian variasi lain menunjukkan trend yang sama dengan respon yang ditunjukkan pada Gambar 7. Hasil pengujian dengan gangguan positif keseluruhan ditunjukkan pada Tabel 6.

Tabel 6. Hasil pengujian dengan gangguan positif.

\begin{tabular}{cccccc}
\hline $\begin{array}{c}\text { Engine } \\
\text { Speed }\end{array}$ & Sistem & \multicolumn{2}{c}{ Gangguan } & Galat Keadaan & ISE \\
\hline 1 & EAT PI & $+30^{\circ}$ & $+20^{\circ}$ & -244 & $3,430.10^{9}$ \\
1 & EAT FPI & $+30^{\circ}$ & $+20^{\circ}$ & 230 & $2,612.10^{\circ}$ \\
1 & EAT PI & $+45^{\circ}$ & $+25^{\circ}$ & -204 & $3,427.10^{\circ}$ \\
1 & EAT FPI & $+45^{\circ}$ & $+25^{\circ}$ & 230 & $2,612.10^{\circ}$ \\
1 & EAT PI & $+60^{\circ}$ & $+10^{\circ}$ & -199 & $3,427.10^{\circ}$ \\
1 & EAT FPI & $+60^{\circ}$ & $+10^{\circ}$ & 230 & $2,612.10^{\circ}$ \\
2 & EAT PI & $+30^{\circ}$ & $+20^{\circ}$ & -47 & $3,900.10^{\circ}$ \\
2 & EAT FPI & $+30^{\circ}$ & $+20^{\circ}$ & -47 & $2,869.10^{\circ}$ \\
2 & EAT PI & $+45^{\circ}$ & $+25^{\circ}$ & 16 & $3,898.10^{\circ}$ \\
2 & EAT FPI & $+45^{\circ}$ & $+25^{\circ}$ & 16 & $2,895.10^{\circ}$ \\
2 & EAT PI & $+60^{\circ}$ & $+10^{\circ}$ & 16 & $3,898.10^{\circ}$ \\
2 & EAT FPI & $+60^{\circ}$ & $+10^{\circ}$ & 16 & $2,895.10^{\circ}$ \\
3 & EAT PI & $+30^{\circ}$ & $+20^{\circ}$ & 161 & $4,930.10^{\circ}$ \\
3 & EAT FPI & $+30^{\circ}$ & $+20^{\circ}$ & 162 & $3,528.10^{\circ}$ \\
3 & EAT PI & $+45^{\circ}$ & $+25^{\circ}$ & 333 & $4,934.10^{\circ}$ \\
\hline
\end{tabular}

Tabel 6. Hasil pengujian dengan gangguan positif (lanjutan).

\begin{tabular}{cccccc}
\hline $\begin{array}{c}\text { Engine } \\
\text { Speed }\end{array}$ & Sistem & \multicolumn{2}{c}{ Gangguan } & Galat Keadaan & ISE \\
\hline 3 & EAT FPI & $+45^{\circ}$ & $+25^{\circ}$ & 354 & $3,532.10^{\circ}$ \\
3 & EAT PI & $+60^{\circ}$ & $+10^{\circ}$ & 251 & $4,932.10^{\circ}$ \\
3 & EAT FPI & $+60^{\circ}$ & $+10^{\circ}$ & 257 & $3,530.10^{\circ}$ \\
4 & EAT PI & $+30^{\circ}$ & $+20^{\circ}$ & 554 & $6,799.10^{\circ}$ \\
4 & EAT FPI & $+30^{\circ}$ & $+20^{\circ}$ & 554 & $5,156.10^{\circ}$ \\
4 & EAT PI & $+45^{\circ}$ & $+25^{\circ}$ & 819 & $6,827.10^{9}$ \\
4 & EAT FPI & $+45^{\circ}$ & $+25^{\circ}$ & 828 & $5,184.10^{9}$ \\
4 & EAT PI & $+60^{\circ}$ & $+10^{\circ}$ & 889 & $6,836.10^{\circ}$ \\
4 & EAT FPI & $+60^{\circ}$ & $+10^{\circ}$ & 894 & $5,193.10^{\circ}$ \\
Rata- & EAT PI & - & - & 195 & $4,77.10^{9}$ \\
rata & & & & & \\
Rata- & EAT FPI & - & - & 310 & $3,468.10^{\circ}$ \\
rata & & & & &
\end{tabular}

Berdasarkan Tabel 6, diketahui bahwa rata-rata nilai ISE sistem cascade fuzzy gain scheduling of PI 37,54 \% lebih rendah dibandingkan sistem cascade fuzzy-PI. Sistem cascade fuzzy gain scheduling memiliki nilai rata-rata galat keadaan tunak 58,9\% lebih tinggi dibanding sistem dengan struktur cascade fuzzy-PI, namun kedua sistem dapat mengatasi gangguan positif dengan rentang galat yang masih dalam batas toleransi.

Pengujian dengan gangguan perpindahan transmisi merupakan pengujian performa sistem saat terjadi gangguan sudut bukaan throttle diperkecil dan diperbesar setelahnya. Pengujian dilakukan dengan kondisi sudut bukaan throttle awal $90^{\circ}$ diturunkan menjadi $5^{\circ}$ pada $t=25$ $\mathrm{s}$ dan transmisi ditingkatkan pada $t=25,5$ kemudian sudut bukaan throttle kembali diperbesar hingga terbuka $90^{\circ}$. Pengujian perpindahan transmisi 1 ke 2 ditunjukkan pada Gambar 8.

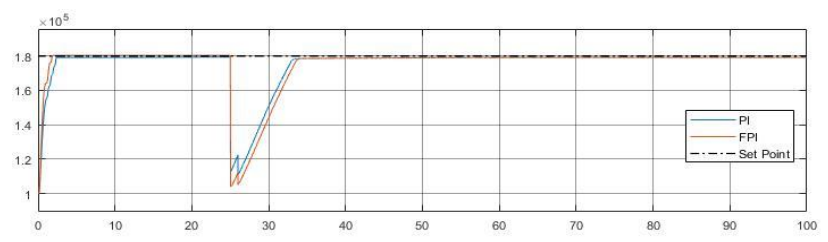

Gambar 8. Respon keluaran sistem pada engine speed 2.000 rpm dengan gangguan negatif $\mathbf{- 3 0}^{\circ}$ dan $\mathbf{- 2 0}^{\circ}$.

Gambar 8 menunjukkan terjadinya penurunan tekanan pada $t=25 \mathrm{~s}$. Hal ini disebabkan oleh terbukanya blow off valve untuk membuang udara yang terperangkap saat throttle ditutup. Dari gambar 8 terlihat bahwa sistem cascade fuzzy gain scheduling of PI dan cascade fuzzy-PI mampu mengatasi gangguan negatif sehingga sistem tetap berada dalam keadaan tunaknya. Hasil pengujian pada Gambar 8 terlihat bahwa sistem EAT PI memiliki respon yang lebih cepat dibanding sistem EAT FPI. Hal ini disebabkan karena sebelum terjadi sudut bukaan throttle diperkecil, sistem EAT FPI memiliki keluaran keadaan tunak diatas set point sedangkan sistem EAT PI memiliki keluaran keadaan tunak dibawah set point sehingga respon motor DC kedua sistem berebda pada keadaan tunak 
sebelum terjadi sudut bukaan throttle diperkecil. Pengujian variasi lain ditunjukkan pada Tabel 7.

Tabel 7. Hasil pengujian dengan gangguan negatif.

\begin{tabular}{ccccc}
\hline $\begin{array}{c}\text { Variasi } \\
\begin{array}{c}\text { Perpindahan } \\
\text { Transmisi }\end{array}\end{array}$ & $\begin{array}{c}\text { Sistem } \\
\text { Kontrol }\end{array}$ & $\begin{array}{c}\text { Kecepatan } \\
\text { Respon (s) }\end{array}$ & $\begin{array}{c}\text { Galat } \\
\text { Keadaan } \\
\text { Tunak }\end{array}$ & ISE \\
\hline $1-2$ & EAT PI & 8 & -877 & $1,872.10^{10}$ \\
& EAT FPI & 8,8 & -866 & $2,262.10^{10}$ \\
$2-3$ & EAT PI & 7,3 & -577 & $1,443.10^{10}$ \\
& EAT FPI & 7,3 & -558 & $1,370.10^{10}$ \\
$3-4$ & EAT PI & 7 & -288 & $1,258.10^{10}$ \\
& EAT FPI & 7 & -288 & $1,131.10^{10}$ \\
Rata-rata & EAT PI & 7,4 & 580,67 & $1,524.10^{10}$ \\
& EAT FPI & 7,7 & 570,67 & $1.587 .10^{10}$ \\
\hline
\end{tabular}

Pada keadaan tunak sebelum terjadi gangguan sudut bukaan throttle diperkecil, motor DC sistem EAT FPI menghasilkan keluaran torsi lawan untuk mencegah tekanan kompresor jauh melebihi set point sedangkan motor DC pada sistem EAT PI menghasilkan torsi driving untuk meningkatkan tekanan kompresor agar mencapai set point. Pada saat sudut bukaan throttle ditutup, blow off valve akan terbuka untuk membuang udara yang terperangkap sehingga tekanan kompresor menurun. Pada saat tekanan kompresor turun karena blow off valve terbuka, motor DC pada sistem EAT FPI masih memberikan respon torsi lawan sehingga tekanan kompresor akan turun tidak hanya karena blow off valve terbuka tetapi juga karena torsi lawan motor DC. Sedangkan pada EAT PI, motor DC masih memberikan respon torsi driving sehingga justru turunnya tekanan terhambat oleh motor DC. Hal tersebut yang menyebabkan hasil pengujian kedua sistem EAT pada perpindahan transmisi 1 ke 2 berbeda.

Pada Tabel 7 terlihat bahwa pada perpindahan transmisi tinggi, kecepatan respon kedua sistem EAT lebih singkat dibandingkan pada perpindahan transmisi rendah. Pada pengujian perpindahan transmisi 2 ke 3 dan 3 ke 4 memiliki kesamaan namun ISE EAT FPI mengungguli EAT PI karena dipengaruhi respon awal sistem. Berdasarkan ratarata hasil pengujian, sistem EAT PI memiliki kecepatan respon sistem 4,05\% lebih singkat dibanding sistem EAT FPI. Galat keadaan tunak sistem EAT FPI 1,72\% lebih rendah dibandingkan EAT PI. ISE EAT FPI 4,13\% lebih tinggi dibandingkan EAT PI, hal ini dikarenakan pada variasi pengujian perpindahan transmisi 1 ke 2 terjadi perbedaan ISE yang besar walaupun pada variasi pengujian perpindahan transmisi lain, ISE EAT FPI selalu lebih rendah dibanding ISE EAT PI.

\section{Kesimpulan}

Kedua sistem EAT pada penelitian ini menunjukkan performa yang mengungguli performa sistem turbocharger konvensional pada semua variasi pengujian. Settling time sistem dengan struktur cascade fuzzy gain scheduling of PI 95,99 \% lebih singkat dibanding sistem turbocharger konvensional, sedangkan sistem dengan struktur cascade fuzzy-PI 95,17 \% lebih singkat dibanding sistem turbocharger konvensional. Kedua sistem EAT memiliki galat keadaan tunak yang masih berada pada rentang toleransi. Kedua sistem EAT mampu menjaga keadaan tunaknya saat dilakukan akselerasi dan perpindahan transmisi sehingga ideal diterapkan pada plant aslinya.

\section{Referensi}

[1] H. Hedfi, A. Jbara, H. Jedli, K. Slimi, and A. Stoppato, "Performance enhancement of a spark ignition engine fed by different fuel types," ENERGY Convers. Manag., vol. 112, pp. 166-175, 2016.

[2] C. Gong, F. Liu, J. Sun, and K. Wang, "Effect of compression ratio on performance and emissions of a strati fi ed-charge DISI ( direct injection spark ignition ) methanol engine," Energy, vol. 96, no. X, pp. 166-175, 2016.

[3] I. Haider, H.-R. Khalid, and U. S. Khan, "An Initial Study of PID and Fuzzy PID Controller Design for Non-Linear SI Engine Speed and AFR Control Performance Analysis Using MATLAB/Simulink," 2014 14th Int. Conf. Control. Autom. Syst. (ICCAS 2014), vol. 437, no. ICCAS 2014, pp. 437-442, 2014.

[4] N. Watson and M. S. Janota, Turbocharging the Internal Combustion Engine. London: The Macmillan Press Ltd., 1982.

[5] A. Jain, T. Nueesch, C. Naegele, P. M. Lassus, and C. Onder, "Modeling and Control of a Hybrid Electric Vehicle with an Electrically Assisted Turbocharger," vol. 9545, no. c, pp. 1-15, 2016.

[6] J. Bumby, S. Crossland, and J. Carter, "Electrically assisted turbochargers: their potential for energy recovery," Hybrid Veh. Conf. IET Inst. Eng. Technol., pp. 43-52, 2006.

[7] J. . Bumby et al., "Electrical machines for use in electrcally assisted turbochargers," Inst. Electr. Eng., pp. 344-349, 2004.

[8] A. Gilson, F. Dubas, D. Depernet, C. Espanet, and A. Presentation, "Comparison of High-Speed PM Machine Topologies for Electrically-Assisted Turbocharger Applications," no. c, pp. 2-6.

[9] J. Rajeevan, M. H. Hans, A. Joseph, T. S. Kiran, and G. Kumaran, "Hybrid turbocharged SI engine with cooled exhaust gas recirculation for improved performance," Procedia Technol., vol. 24, pp. 444-451, 2016.

[10] F. Pettersson, "Simulation of a Turbo Charged Spark Ignited Engine," Link" oping Universitet, 2000.

[11] J. Wahlstrom and L. Eriksson, "Modelling Diesel engines with a Variable-Geometry Turbocharger and Exhaust Gas Recirculation By Optimization of Model Parameters for Capturing Non-Linear System Dynamics," Proceeding IMechE, vol. 225, no. x, pp. 960-986, 2014.

[12] S. L. Dixon, Fluid Mechanics , Thermodynamics of Turbomachinery, Fourth. Oxford: ButterworthHeinemann, 1998.

[13] R. Jongeneel, "Input Redundant Internal Combustion Engine with Linear Quadratic Gaussian Control and Dynamic Control Allocation," Melbourne, 2009. 